\title{
ELEMENTS OF AUTOMATIC CONTROL OF HYDRODYNAMIC SYSTEMS
}

\author{
Anatoli M. Voronin ${ }^{1}$, Bekmurza H. Ajtchanov², Janusz Partyka ${ }^{3}$, Aitkul Aldibekova ${ }^{2}$ \\ ${ }^{1}$ Almaty Technological University, ${ }^{2}$ Kazakhstan National Technical University named after K.I.Satpayev, ${ }^{3}$ Lublin University of Technology
}

Abstract. The paper presents the automated system of control of certain elements of the hydrodynamic system related to the production of liquid milk. Similar systems may find application in various fields of engineering, such as: hydro power station construction; oil refineries construction; control systems in various chemical industries containing hydrogen atoms in the final product; in propellant flow rate systems, etc., whenever it is required to control hydrodynamic parameters by means of nuclear magnetic resonance on the relevant atoms of the products used.

Keywords: the automated control system, hydrodynamics, nuclear magnetic resonance

\section{ELEMENTY KONTROLI ZAUTOMATYZOWANYCH SYSTEMÓW HYDRODYNAMICZNYCH}

Streszczenie. Artykut prezentuje zautomatyzowany system sterowania wybranymi elementami systemu hydrodynamicznego wykorzystywanego przy produkcji mleka. Podobne systemy moga znaleźc zastosowanie $w$ innych obszarach zastosowań, np. hydroelektrowniach, rafineriach, zakładach chemicznych, układach paliwowych, itp., gdzie jest wymagane kontrolowanie parametrów hydrodynamicznych za pomoca jądrowego rezonansu magnetycznego.

Słowa kluczowe: zautomatyzowany system kontroli, mechanika płynów, rezonans jądrowy

\section{Introduction}

A number of studies $[4,8]$ examined various automated control systems of technological processes. Fundamentals of the theory of control systems are incorporated in the works $[1,2]$. We proposed to use the nuclear magnetic resonance [9] on the hydrogen atoms as a probe of the magnetic field in the magnetization of milk. This technology can increase overall system accuracy of autoregulation.

\section{System of automated control}

In the devices intended for the magnetization of milk aimed at improvement of the physico-chemical properties of milk it is necessary to maintain several constant parameters. To obtain stable output parameters it is necessary on the one hand to have a high degree of accuracy in controlling the speed of the milk flowing through the pipelines, and keep it constant for a long time. On the other hand the magnetic field should be monitored with its subsequent stabilization. These parameters may vary in proportions depending on the type of equipment.

There are various devices for maintaining the continuance of liquid flow through the pipeline, such as the use of modified Mariotte vessels. This paper considers a more general approach for getting a stabilized flow of fluid in the experimental installation.

Figure 1 shows a block diagram of the apparatus. The milk from dairy farms is loaded into the reservoir (1), which through the pipeline (2) is fed into a control unit (3) equipped with an auto regulation system (4) controlled by the liquid flow rate sensor through the pipeline (5). Then, the milk flows through a pair of quadrupole lenses (6) which produce a preset level of magnetic field whose value is regulated by an automatic control system (7) connected with the sensor of magnetic field intensity level (8).

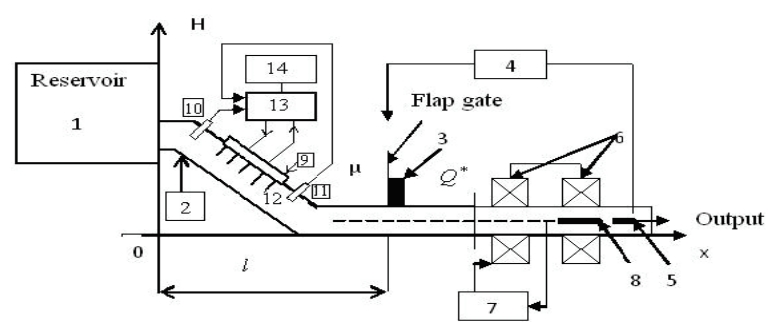

Fig. 1. General block diagram of the apparatus

The temperature of the incoming product for the milk magnetizing system should be 3-4 0C. For this purpose the fluid control system is based on the Peltier effect. The controller is made of flat parallel aluminium plates located inside the pipe (12) cooled with a Peltier element (9) the heat from which is diverted through the radiator installed outside the pipe (14), air-cooled. In order to maintain the temperature of milk in the tube within the limit of $3 \pm 0,50 \mathrm{C}$ an electronic control device (13) is used for the temperature sensors $(10,11)$ in the form of thermistors incorporated into the scheme of the temperature controller. External heat is is diverted through the air-blown radiator.

We propose an approach that provides a transition from hydrodynamics to the automatic control system of a liquid flow rate.

Dynamic processes in the pipeline are characterized by the two variables: by the pressure $H^{*}$ and by the flow rate $Q^{*}$,

$$
\frac{\partial h}{\partial x}=\frac{\gamma}{\alpha} \cdot \frac{\partial q}{\partial t} ; \frac{\partial q}{\partial x}=-\frac{1}{\gamma \alpha} \cdot \frac{\partial h}{\partial t}
$$

where $h=\frac{H^{*}}{H_{* 0}}, \quad q=\frac{Q^{*}}{Q_{0}^{*}}-$ the relative values of pressure and flow, respectively, $H_{0}^{*}, Q_{0}^{*}-$ basic values of $H^{*}, Q^{*}$, $\alpha$ - acoustic velocity in the pipeline, $\gamma=\frac{a Q_{0}^{*}}{g F H_{0}^{*}}, g-$ free-fall acceleration, $F$ - cross-sectional area of the pipeline.

After the transformations we receive the following equation for the originals:

$$
u(l, t)=2 h(O, t-\tau)-h(l, t-2 \tau)+\gamma q(l, t-2 \tau)-\gamma q(l, t)
$$

The given equation links the two basic quantities $h(l, t)$ and $q(l, t)$ at the end of the pipeline with a pressure at its beginning $h(o, t)$. In order to make the task definite, the equation of the flow rate $q(l, t)$ should be added to the equation (2):

$$
q(l, t)=\mu f[h(l, t)] \approx \mu \sqrt{1+h(l, t)}
$$

The joint solution of equations (2) and (3) determines the basic values $h(1, t)$ and $q(1, t)$ at the end of the pipeline with the definite values of the pressure $h(o, t)$, at its beginning and in the position of the gate $\mu$.

The analysis of the equation (2) shows that the length of the pipeline can be replaced (by an electric model) (in the course of developing automatic control systems) by reinforcing components with delay, and by the performing a linearization of the equation (3) we can apply the methods of the analysis of linear systems with delay $[3,5]$.

Therefore a block diagram of the model designed to determine the value $\left.h(t)\right|_{x=l}$ and $\left.q(t)\right|_{x=l}$, i.e. to determine the changes in pressure and flow at the point $x=l$ (Fig. 2), is composed on the basis of equations (2) and (3). The signals proportional to $h(o, t)$ and $\mu$ are sent to the input; they pass through the model elements and transform to the unknown variables $h(l, t)$ and $q(l, t)$. Similar systems of diagnostics are applied in paper [6].

This conclusion about the possibility of recording components with distributed parameters by the components with delay follows from the physical considerations: an object with distributed parameters can be represented by $n$ as series-connected elementary components of the first order; and such components can be represented by a delayed component.

Because of the transcendence of the transfer function of a delay component, the characteristic equation of the closed-loop system 
is also transcendental; so the algebraic criteria for stability cannot be used directly. However, partial criteria of Mikhailov and Nyquist can be generalized for the case of delay systems, i.e. the system under consideration is stable [7].

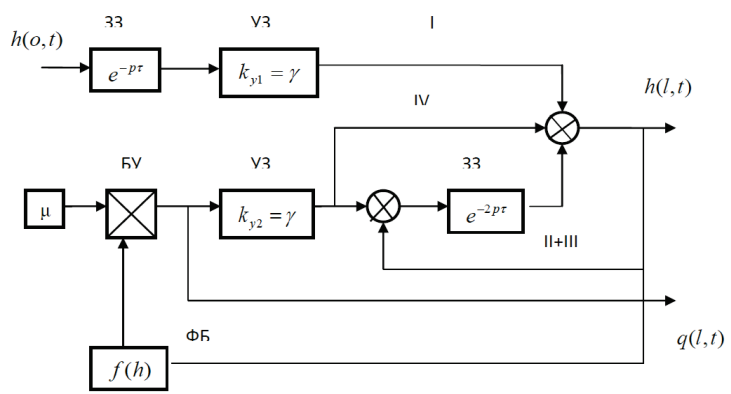

Fig. 2. The block diagram of the model: 33 - delay unit; 13 - intensifying unit; $Б У$ - multiplying unit; $\Phi Б$ - functional unit with the input $h(l, t)$ and output $f(h)=\sqrt{1+h(1, t)} ; I, I I, I I I, I V$ - composing equations (I)

For many processes the characteristic feature is a significant time lag response of the object (the change of the output value $y$ ) to the change of the control action $u$. According to the calculations for a particular value of the ratio of the delay time of the object $\tau_{0}$ to its time constant $T_{0}$ (for instance, at $\tau_{0} / T_{0}>0.5$ ) the effectiveness of the control laws is sharply reduced because of the large static (P, PD-laws) or dynamic (I, PI, PID - laws) errors, and in some cases, the system may become unstable. Therefore there were developed special (non-classical) laws of control: proportional-integral-differential (PIR - law) and proportionalintegral by the background (PIP - law). In contrast to the classical control laws that use only the information about the deviation of the controlled value from the given value $y^{*}\left(\Delta=y^{*}-y\right)$, here is used a priori information about the controlled object on the basis of which the classical control law

$$
u(t)=k_{1} \Delta(t)+k_{2} \int_{0}^{t} \Delta(t) d t+k_{3} \frac{d \Delta(t)}{d t},
$$

where $k_{i}$ - coefficient of proportionality (transfer) in order to make certain corrections. In the case of a parallel transfer the correction function of the adjusted control law $W_{y}^{d k}(P)$ can be written as

$$
W_{y}^{c u}(P)=W_{\delta}(P)+W_{k}(P)
$$

where $W_{\delta}(P), W_{k}(P)$ - transfer functions of the base-level control and correction unit.

In connection with the above-described process the control block diagram of the control panel-controller can be represented as it is given in Figure 3.

The analysis of this scheme shows that the control action is formed as the algebraic sum of the two components: $u_{\delta}$ - the component on the output of PI - regulator; $u_{k}$ - the component unit of a parallel correction. The introduction of the component $u_{k}$ weakens the proportional and integral part of the basic component ( $k_{1}$ and $k_{2}$ are less than one) at $t>\tau_{0}$ The latter condition is ensured by the introduction of component 4 , which is a model of a controlled object. Therefore, the PIP - the regulator provides a high level of control action $u=u_{\delta}$ at $t>\tau_{0}$ and gradual decline of this level at $t>\tau_{0}\left(u=u_{\delta}-u_{k}\right)$.

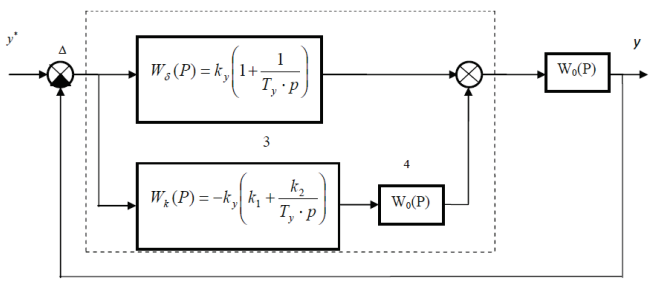

Fig. 3. Block diagram of automated control panel with PIP system: 1- control panel; 2-PI-regulator; 3,4-correction units; 5-PIP-regulator
Like in the case with the PIR - regulator, the implementation of the PIP - control law improves the quality of a transient stability process and increases the absolute stability margin in the amplitude and phase compared to the PI-regulator. Besides, the parameter settings of the correction component $k_{1}$ and $k_{2}$ because of their linear relation to the proportional and integral components of the output correction signal 3 is quite simple.

Therefore, the introduction of delayed components into the structure of a parallel correction component can significantly enhance the quality of transient processes to the ACS by the objects with a significant delay, as in the system of milk magnetization.

\section{Literature}

[1] Aleksandrov A. G.: Optimal'nye i adaptivnye sistemy.M, Vysshaja shkola 1989.

[2] Fradkov A. L.: Adaptivnoe upravlenie v sozhnyh sistemah. M, Nauka 1990.

[3] Makarova I.M., Lohchena V.M.: Intelektual'nye sistemy avtomaticheskogo upravlenija. M,Fizmatgiz 2001.

[4] Miroshnik I. V.: Teorija avtomaticheskogo upravlenija. Linejnye sistemy. SPb, Piter 2005.

[5] Popov E. P.: Teorija linejnyh sistem avtomaticheskogo regulirovanija i upravlenija. M, Nauka 1989.

[6] Sulejmenov B.A., Shuvatov T.T.: Metodika postroenija sistemy diagnostiki GPA. № 4 (30), Inzhenerno tehnicheskij zhurnal «Vestnik avtomatizacii», 12/ 2010, s. 7-9.

[7] Syzdykov D.Zh., Shirjaeva O.I., Omirbekova Zh.Zh.: Razvitie metoda obwego parametra dlja immunnoj modeli. Inzhenerno tehnicheskij zhurnal «Vestnik avtomatizacii», № 3 (25), 9/ 2009, s. 31-33.

[8] Voronin A. M., Aldibekova A. N.: O stabilizacii magnitnyh polej jelektrofizicheskih ustanovok $\mathrm{s}$ ispol'zovaniem JaMR. Vestnik Nacional'noj Inzhenernoj Akademii RK 2/2012, s. 80-84.

[9] Vlasov K. P.: Teorija avtomaticheskogo upravlenija. Uchebnoe posobie. H, Izd-vo Gumanitarnyj centr 2007.

\section{Prof. Voronin Anatoli Mikhailovich}

e-mail: voronin.ski@rambler.ru

Professor, expert in nuclear physics and accelerators, Full Member of the International Engineering Academy (instrument engineering), Academician of the National Engineering Academy of the Republic of Kazakhstan (accelerators of charged particles). At present he works as a professor of the chair of physics at the Almaty Technological University.

Fields of interest: nuclear physics; high-frequency systems of charged-particle accelerators; radioecology; information and communication technologies; electronic pedagogy in high-education institutions.

\section{Prof. Aitchanov Bekmurza Husainovich}

e-mail: berait@rambler.ru

Dr.Sci.Tech., Professor, Academician of the International Academy of Information and Academician of the Kazakhstan National Academy of Natural Sciences. He published more than 205 research papers. $\mathrm{He}$ teaches the following disciplines: «Information technologies», «Theory of the information», «Designing of information systems». His experience of scientific and pedagogical activity is 37 years.

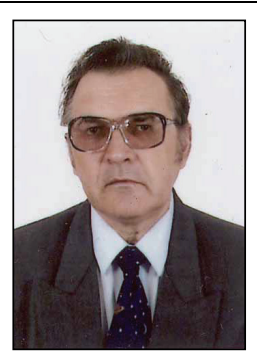

\section{Prof. Janusz Partyka}

e-mail: j.partyka@pollub.pl

$\mathrm{He}$ is employed at the Lublin University of Technology, Department of Electrical Engineering and Information Science as a university professor. $\mathrm{He}$ is the author or co-author of over 150 scientific publications and has been a supervisor of several dozens of graduate theses. His research interests focus on electronic materials and technologies.

\section{Aldibekova Aitkul}

e-mail: aitkul_86@mail.ru

A PhD student of Satpayev Kazakh National Technical University in "Automation and Control." A co-author of eight publications.
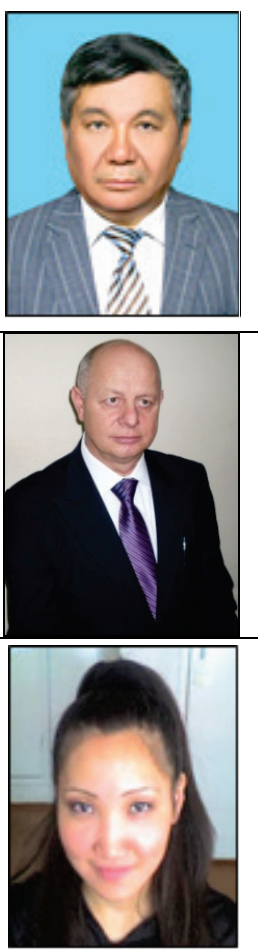